Article

\title{
Empirical Analysis and Geomechanical Modelling of an Underground Water Reservoir for Hydroelectric Power Plants
}

\author{
Javier Menéndez ${ }^{1, *(1)}$, Falko Schmidt ${ }^{2}$, Heinz Konietzky ${ }^{3}$, Antonio Bernardo Sánchez ${ }^{4} \mathbb{C}$ and \\ Jorge Loredo ${ }^{5}$ \\ 1 Renewable Energy Department, Hunaser Energy, Avda. Galicia 44, 33005 Oviedo, Spain \\ 2 Geomechanical Department, Geotechnical Engineer, 39011 Santander, Spain; falko@geomecanica.es \\ 3 Geotechnical Institute, TU Bergakademie Freiberg, 09599 Freiberg, Germany; \\ Heinz.Konietzky@ifgt.tu-freiberg.de \\ 4 Department of Mining Technology, Topography and Structures, University of León, 24071 León, Spain; \\ abers@unileon.es \\ 5 Department of Mining Exploitation, University of Oviedo, 33004 Oviedo, Spain; jloredo@uniovi.es \\ * Correspondence: jmenendezr@hunaser-energia.es; Tel.: +34-985107300
}

Received: 28 July 2020; Accepted: 20 August 2020; Published: 24 August 2020

\begin{abstract}
The European Union policy of encouraging renewable energy sources and a sustainable and safe low-carbon economy requires flexible energy storage systems (FESSs), such as pumped-storage hydropower (PSH) systems. Energy storage systems are the key to facilitate a high penetration of the renewable energy sources in the electrical grids. Disused mining structures in closed underground coal mines in NW Spain have been selected as a case study to analyze the construction of underground pumped-storage hydropower (UPSH) plants. Mine water, depth and subsurface space in closured coal mines may be used for the construction of FESSs with reduced environmental impacts. This paper analyzes the stability of a network of tunnels used as a lower water reservoir at $450 \mathrm{~m}$ depth in sandstone and shale formations. Empirical methods based on rock mass classification systems are employed to preliminarily design the support systems and to determinate the rock mass properties. In addition, 3D numerical modelling has been conducted in order to verify the stability of the underground excavations. The deformations and thickness of the excavation damage zones (EDZs) around the excavations have been evaluated in the simulations without considering a support system and considering systematic grouted rock bolts and a layer of reinforced shotcrete as support system. The results obtained show that the excavation of the network of tunnels is technically feasible with the support system that has been designed.
\end{abstract}

Keywords: mining structures; underground reservoir; empirical analysis; numerical modelling; energy storage; hydropower plants

\section{Introduction}

In the current evolving energy context, characterized by an increasing of variable renewable energy (VRE) in the electricity mix, the development of flexible energy storage systems (FESSs), such as pumped storage hydropower (PSH) or compressed air energy storage (CAES) plants are required. PSH is the most mature technology to provide ancillary services to the electrical grid [1]. PSH systems accounted for $150 \mathrm{GW}$ worldwide in 2016 (40 GW in the European Union) [2] and the capacity could be $325 \mathrm{GW}$ in 2030 [3].

Underground pumped storage hydropower (UPSH) is an alternative to store large amounts of electrical energy with low environmental impacts $[4,5]$. Other energy storage systems such as 
Li-ion batteries are more efficient, but more expensive to install [6,7]. Geomechanical studies of the underground infrastructure are required to assess the technical feasibility of subsurface energy storage plants. Menendez et al. [8] carried out a stability analysis of the underground infrastructure of UPSH plants in closed mines. The stability of the powerhouse cavern and the effect of air pressure on the excavations (tunnels and air shafts) during the operation time were analyzed. Uddin and Asce [9] studied the behavior of a limestone mine as UPSH plant, at $671 \mathrm{~m}$ depth with a volume of 9.6 million $\mathrm{m}^{3}$. Carneiro et al. [10] presented the opportunities for large-scale energy storage in geological formations in mainland Portugal. UPSH, CAES and gas storage systems (hydrogen and methane) were analyzed. Khaledi et al. [11] analyzed compressed air storage caverns in rock salt considering thermo-mechanical cyclic loading. The study concludes that the stability is affected by the operating pressure $(10 \mathrm{MPa})$ and the increased creep rate accelerates the volume convergence. Liu et al. [12] applied empirical analysis and numerical methods to provide a support design for an underground water-sealed oil storage cavern. Chen et al. [13] developed a numerical model to analyze the stability of a small-spacing two-well salt cavern used as gas storage. Rutqvist et al. [14] investigated the thermodynamic and geomechanical performance of CAES systems in concrete-lined rock caverns. Zhu et al. [15] developed an equation for prediction of displacement at the key point on the high sidewalls of powerhouse caverns, considering four basic factors (the rock deformation modulus, the overburden depth, the height of the powerhouse and the lateral pressure coefficient of the initial stress). Harza [16] suggested the idea to use a closed underground mine as a lower reservoir and develop an UPSH plant in 1960. At the end of the 1960s, Swedish engineers proposed the exploitation of a surface upper reservoir and the construction of a new lower water reservoir in an underground rock cavern [17]. Sorensen suggested an optimistic future for the development of UPSH plants [18]. The Mount Hope project, located in northern New Jersey (USA) was proposed in 1975 [19]. It intended to use the facilities of a closed iron mine as a lower water reservoir, but it was never developed. In 1978, an UPSH project was presented with a lower reservoir formed by a network of $15 \times 25 \mathrm{~m}$ elliptical tunnels, at a depth of $1000 \mathrm{~m}$ [20]. During the 1980s, a project to install an UPSH plant was proposed in the Netherlands [21], but the project was finally not developed due to the poor quality of the rock mass. Wong assessed the possibility of constructing UPSH plants in the Bukit Timah granite of Singapore [4]. Coal mining structures in closed underground coal mines in the Asturian Central Coal Basin (ACCB), NW Spain, have been proposed as a lower water reservoir of UPSH plants [22,23]. Recently, several studies have been also carried out in Germany to assess the possibilities to develop UPSH plants on closed underground coal mines in the Harz and Ruhr regions [24-26]. Pujades et al. [27] and Kitsikoudis et al. [28] proposed a closed slate mine in Belgium as a lower reservoir of an UPSH plant. The slate mine consists of nine large caverns with an available volume of 550,000 $\mathrm{m}^{3}$.

This paper analyzes the stability of a network of tunnels as a lower water reservoir at $450 \mathrm{~m}$ depth in sandstone and shale rock formations in closed mines. The rock mass was characterized according to the rock mass quality (Q-System) and the rock mass properties were estimated. In addition, 3D numerical analysis using FLAC 3D have been performed to verify the stability of the excavations. The maximum thickness of the excavation damage zone (EDZ) and the vertical and horizontal displacements when the support system is applied have been compared to the unsupported case in central and transversal tunnels. The axial force, bending moment and shear force in the shotcrete layer have also analyzed. The results obtained show that the excavation of the network of tunnels is technically feasible with the support system that has been designed.

\section{Methodology}

\subsection{Preliminary Energy Balance}

The storable amount of electricity in UPSH systems depends on the reservoirs' capacity and the hydraulic net head [26]. Figure 1 shows the stored energy per cycle in a closed coal mine considering water masses between $0.1-0.5 \mathrm{Hm}^{3}$ and net heads between $100-600 \mathrm{mH}_{2} \mathrm{O}$. A Francis turbine efficiency 
of $90 \%$ in turbine and pump modes has been considered [29]. Finally, the power output and the power input of the turbines depends on the time at full load. The energy storage reaches $480 \mathrm{MWh}^{\mathrm{Cycle}} \mathrm{C}^{-1}$ considering a gross head of $450 \mathrm{mH}_{2} \mathrm{O}$ and a useful water capacity of $450,000 \mathrm{~m}^{3}$.

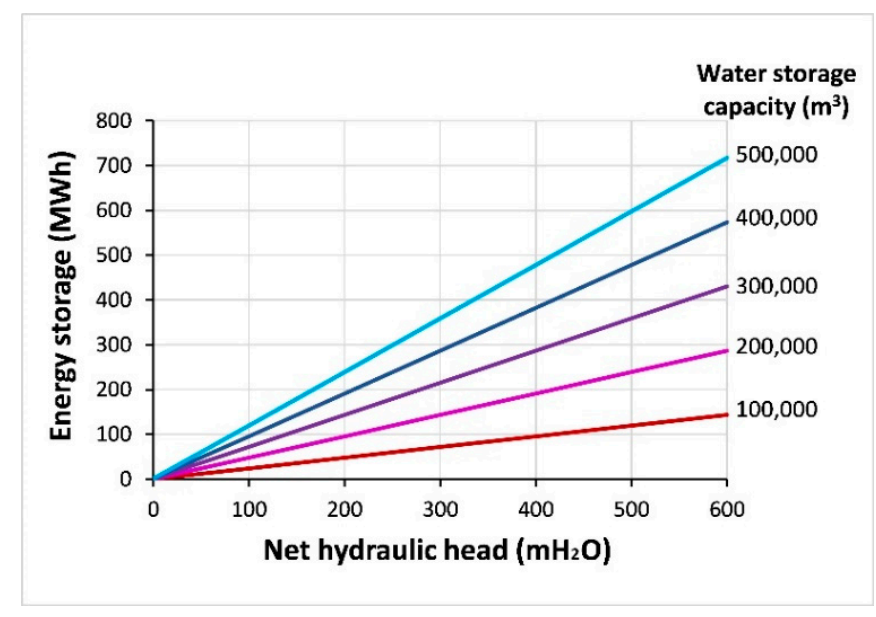

Figure 1. Storable amount of energy of an UPSH plant, considering a turbine efficiency of $90 \%$.

\subsection{Geology}

The Asturian Central Coal Basin (ACCB) is a coal mining area located in NW Spain. It is precisely in the ACCB where the terrigenous carboniferous sediments are best represented, reaching a thickness close to $6000 \mathrm{~m}$ between the Namurian B and Westfalian D. The succession is divided at large scale into two sectors: one lower denominated Lena Group, characterized by limestones and thin seams of coal, and another superior called Sama Group, in which limestones are less abundant and there are levels of sandstones, shales and seams of exploitable bituminous and hard coal [8].

\subsection{Underground Hydroelectric Power Plant}

UPSH systems consist of two water reservoirs; the upper reservoir is located above ground, while the lower reservoir is underground. The scheme of an underground hydroelectric power plant and lower water reservoir is shown in Figure 2a. In the present work, a subsurface water reservoir conformed by a new network of tunnels with an arched roof and straight walls cross-section of $30 \mathrm{~m}^{2}$ (Figure $2 b$ ) is considered. The water reservoir consists of a central tunnel connected to the ventilation shaft, and $200 \mathrm{~m}$ length of transversal tunnels with a distance between them of $20 \mathrm{~m}$. To avoid water leakage, the tunnels' surface is covered with an impermeable high-strength membrane.

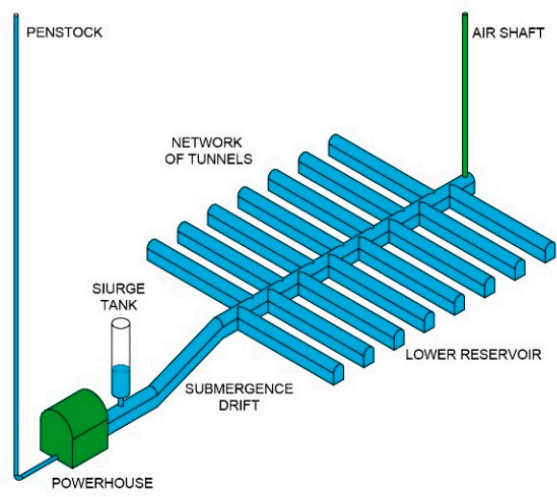

(a)

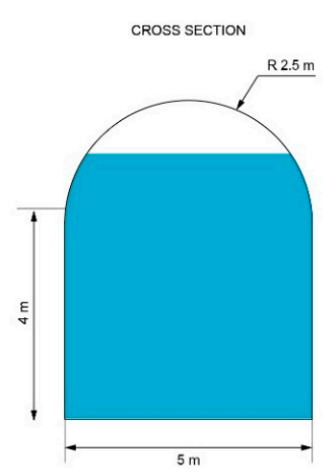

(b)

Figure 2. (a) Scheme of an UPSH plant with a lower water reservoir and an air shaft in a closed underground coal mine; (b) cross section of tunnels. 


\subsection{Empirical Analysis}

The Q-system method was developed by Barton et al. [30] in the Norwegian Geotechnical Institute (NGI) to classify rock masses. The method is based on about 200 case histories of caverns and tunnels. The Q-system has been updated and it is now based on 1260 case records [31]. Barton carried out some changes and adapted it to give support recommendations due to the increasing use of steel fibre reinforced shotcrete (SFR) in underground excavation support [32]. The quality of rock masses (Q) is obtained by applying Equation (1).

$$
\mathrm{Q}=\frac{R Q D}{J_{n}} \frac{J_{r}}{J_{a}} \frac{J_{w}}{S R F}
$$

where $R Q D$ is the rock quality designation, $J_{n}$ is the joint set number, $J_{r}$ is the joint roughness, $J_{a}$ is the joint alteration, $J_{w}$ is the water reduction factor and $S R F$ is the stress reduction factor. The $\mathrm{Q}$ value varies from 0.001 for exceptionally poor quality to 1000 for an exceptionally good quality rock mass. A stress-free form $Q_{N}$ was defined by Goel et al. [33], which is given by Equation (2).

$$
Q_{N}=\frac{R Q D}{J_{n}} \frac{J_{r}}{J_{a}} J_{W}
$$

Barton defined a new parameter $Q_{C}$ (Equation (3)) to improve the correlation among the engineering parameters, where $\sigma_{c i}$ is the strength of intact rock in MPa [32].

$$
Q_{C N}=Q \frac{\sigma_{c i}}{100}
$$

The bolt length $\left(L_{b}\right)$ may be calculated in terms of the excavation width B, by the Equation (4), proposed by Barton et al. [30].

$$
L_{b}=2+(0.15 \mathrm{~B})
$$

\subsection{Material Properties}

The physical and mechanical properties of the shale and sandstone were obtained from laboratory testing at the University of Oviedo Rock Mechanics Laboratory on intact rock samples following International Society Rock Mechanics (ISRM) methods [34]. Table 1 shows the properties of the intact rocks and the geological strength index (GSI). The rock mass properties were determined by means of empirical methods considering a blast damage factor $D=0.8$. Table 2 shows the rock mass properties of the shale and sandstone formations that have been employed as input data in the numerical analysis.

Table 1. Properties of intact rocks.

\begin{tabular}{lccccc}
\hline Lithology & $\begin{array}{c}\text { Unit Weight, } \\
\gamma\left(\mathrm{KN} \mathrm{m}^{-3}\right)\end{array}$ & $\begin{array}{c}\text { Intact Modulus, } E_{\boldsymbol{i}} \\
\mathbf{( M P a )}\end{array}$ & $\begin{array}{c}\text { Compressive } \\
\left.\text { Strength, } \sigma_{\boldsymbol{c} i} \mathbf{( M P a}\right)\end{array}$ & $\begin{array}{c}\text { Intact Rock } \\
\text { Constant }\left(\boldsymbol{m}_{\boldsymbol{i}}\right)\end{array}$ & GSI \\
\hline Shale & 23.83 & 28,988 & 59.7 & 9.2 & 35 \\
Sandstone & 25.87 & 43,650 & 150.8 & 15.4 & 50 \\
\hline
\end{tabular}

Table 2. Rock mass properties considered in the models.

\begin{tabular}{lccccc}
\hline Lithology & $\begin{array}{c}\text { Young's Modulus } \\
\text { (MPa) }\end{array}$ & Poisson's Ratio & $\begin{array}{c}\text { Tensile Strength } \\
\mathbf{( M P a})\end{array}$ & $\begin{array}{c}\text { Cohesion } \\
(\mathbf{M P a})\end{array}$ & $\begin{array}{c}\text { Friction Angle } \\
\left({ }^{\circ}\right)\end{array}$ \\
\hline Shale & 3287 & 0.27 & 0.048 & 0.82 & 37.7 \\
Sandstone & 13,409 & 0.25 & 0.226 & 2.02 & 52.7 \\
\hline
\end{tabular}

\subsection{Numerical Modelling}

To verify the results of the empirical analysis, a 3D numerical analysis was developed. FLAC 3D commercial software was applied to obtain the deformations and the failure states considering the 
excavation of the network of tunnels and the support system $[9,15,35]$. Figure 3 shows the geometry of the models of the lower reservoir in the form of a network of tunnels that have been selected to conduct the numerical analysis. The size of the transversal tunnels model (Figure 3a) is $82.5 \mathrm{~m}$ long, $12.5 \mathrm{~m}$ wide and $69 \mathrm{~m}$ high, and the central tunnel-junction zone model (Figure 3b) is $174 \mathrm{~m}$ long, $12.5 \mathrm{~m}$ wide and $80 \mathrm{~m}$ high. It is assumed that there are roller boundaries at the bottom and along the sides and there is an unconstrained boundary at the top of model for application of uniform vertical stress, in order to simulate the primary stress field. The mesh was refined close to the contour of the excavations and gradually was coarser at positions outwards, for increasing the accuracy of the calculations.

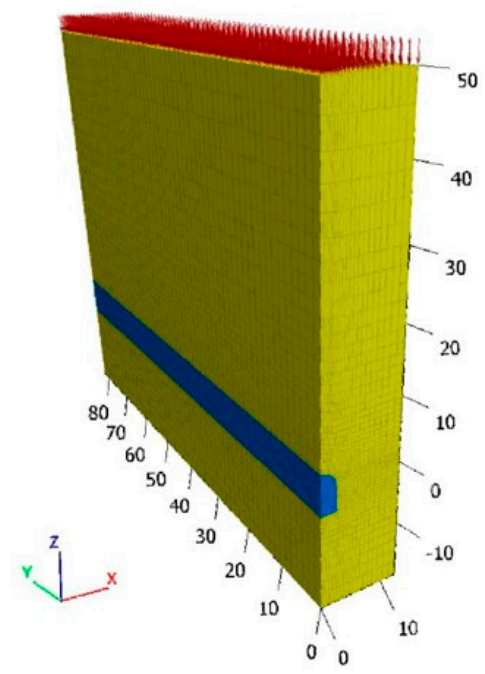

(a)

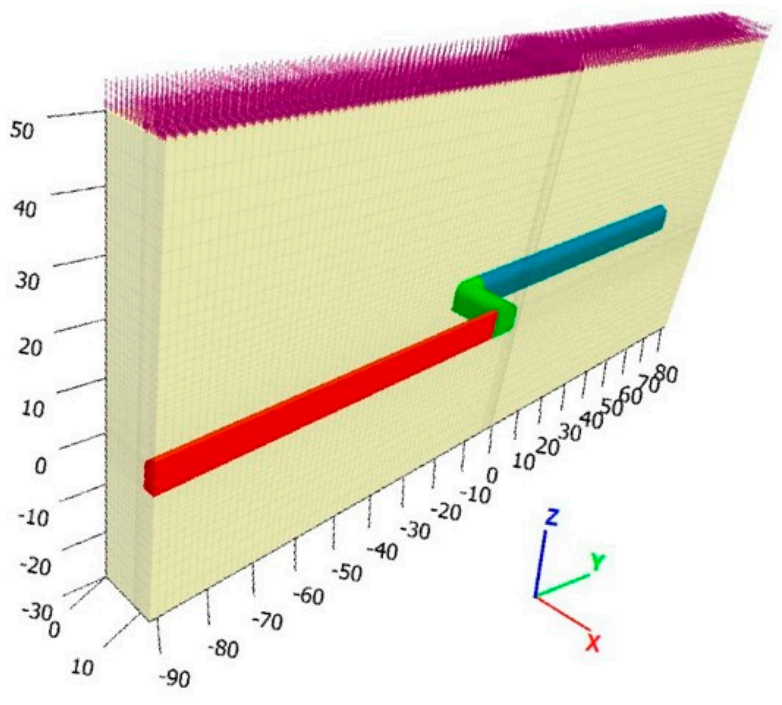

(b)

Figure 3. Geometry of the models of the network of tunnels: (a) transversal tunnels; (b) central tunnel-junction zone.

\subsection{Simulation Procedure}

For the models of the network of tunnels, the solution steps included: (1) establishment of the initial stress field by applying vertical and horizontal stresses and once equilibrium was reached deformations are reset, (2) excavation of the central and transversal tunnels, and (3) installation of the support system immediately after excavation. Failure states and total displacements caused by excavations and installation of the support system were analyzed. The rock mass is considered as homogenous and linearly elastic-perfectly plastic, according to the Mohr-Coulomb (M-C) field criterion. Plastic failure occurs when the shear stress on a certain plane reaches a limit called the shear yield stress. The M-C failure criterion is expressed in Equation (5).

$$
\frac{1}{2}\left(\sigma_{1}-\sigma_{3}\right)=c \cos \phi-\frac{1}{2}\left(\sigma_{1}+\sigma_{3}\right) \sin \phi
$$

where $\sigma_{1}$ and $\sigma_{3}$ are the maximum and minimum principal stresses, respectively, in MPa, $c$ is the cohesion, in $\mathrm{MPa}$, and $\phi$ is the friction angle, in degrees. The initial primary stress field at the tunnels' depth of $450 \mathrm{~m}$ is $10.35 \times 10^{6} \mathrm{~Pa}$ in the vertical direction and $5.17 \times 10^{6} \mathrm{~Pa}$ in the horizontal direction, considering a density of $23 \mathrm{KN} \mathrm{m}^{-3}$. The in-situ horizontal stresses were obtained from the empirical equations from global data and a compilation of such data within the ACCB.

\subsection{Numerical Modelling. Support System Design}

Table 3 shows the design of the support system in the transversal tunnels and the central tunnel for the existing rock masses in the study area. The bolt lengths were calculated by Equation (4), as $2.75 \mathrm{~m}$; 
therefore, the rock bolt length design was $3 \mathrm{~m}$. In the shale formation grouted rock bolts were selected with the following specifications: $25 \mathrm{~mm}$ diameter, $245 \mathrm{KN}$ (25 t) of load capacity, $3 \mathrm{~m}$ long, and spacing between bolts of $1.2 \mathrm{~m}$. Furthermore, there was a layer of $150 \mathrm{~mm}$ thick reinforced shotcrete in the central tunnel and a layer that was $120 \mathrm{~mm}$ thick in transversal tunnels. In the sandstone formation, grouted rock bolts were selected with the following specifications: $25 \mathrm{~mm}$ in diameter, $245 \mathrm{kN}$ of load capacity, $3 \mathrm{~m}$ long, and spacing between bolts of $1.5 \mathrm{~m}$. A layer of $80 \mathrm{~mm}$ thick reinforced shotcrete in the central tunnel and $60 \mathrm{~mm}$ thick in transversal tunnels is also simulated.

Table 3. Support system design.

\begin{tabular}{lc}
\hline \multicolumn{1}{c}{ Shale Rock Mass } \\
\hline $\begin{array}{l}\text { Central tunnel } \\
\text { Transversal tunnels }\end{array}$ & $\begin{array}{l}\text { Systematic bolting } 245 \mathrm{kN}, \phi=25 \mathrm{~mm}, L=3 \mathrm{~m} \text {, Reinforced shotcrete } 150 \mathrm{~mm} \\
\text { Systematic bolting } 245 \mathrm{kN}, \phi=25 \mathrm{~mm}, L=3 \mathrm{~m} \text {, Reinforced shotcrete } 120 \mathrm{~mm}\end{array}$ \\
\hline \multicolumn{1}{c}{ Sandstone Rock Mass } \\
\hline $\begin{array}{l}\text { Central tunnel } \\
\text { Transversal tunnels }\end{array}$ & $\begin{array}{l}\text { Systematic bolting } 245 \mathrm{kN}, \phi=25 \mathrm{~mm}, L=3 \mathrm{~m} \text {, Reinforced shotcrete } 80 \mathrm{~mm} \\
\text { Systematic bolting } 245 \mathrm{kN} \phi=25 \mathrm{~mm}, L=3 \mathrm{~m} \text {, Reinforced shotcrete } 60 \mathrm{~mm}\end{array}$ \\
\hline
\end{tabular}

\section{Results and Discussion}

\subsection{Q-System Method}

To estimate the support system it is necessary to establish an equivalent diameter for the tunnel, $\mathrm{D}_{\mathrm{e}}$, which is the width/height of excavation divided by the ESR (excavation support ratio), which for transversal tunnels can be established at 1.3 , so $D_{e}=5.0$. For the central tunnel, a value of ESR of 1.0 has been estimated, obtaining an equivalent diameter for the tunnel, $D_{e}=6.5$. The evaluations of rock masses in sandstone and shale rock masses by using the Q-system and the GSI are summarized in Table 4. By applying Equation (1), in sandstone formation a value of $Q$ of 1.27 is obtained, while in the shale rock mass the value of $Q$ is 0.23 .

Table 4. Evaluating results using the Q-system.

\begin{tabular}{cccccccccc}
\hline Lithology & $\boldsymbol{R} Q \boldsymbol{D}$ & $J_{\boldsymbol{n}}$ & $\boldsymbol{J}_{\boldsymbol{r}}$ & $\boldsymbol{J}_{\boldsymbol{a}}$ & $\boldsymbol{J}_{\boldsymbol{w}}$ & $S R \boldsymbol{F}$ & $\mathbf{Q}$ & $Q_{\boldsymbol{N}}$ & $\boldsymbol{G S I}$ \\
\hline Shale & 31 & 15 & 1 & 2 & 0.4 & 1.8 & 0.23 & 0.41 & 35 \\
Sandstone & 48 & 12 & 1.4 & 2.2 & 0.5 & 1 & 1.27 & 1.27 & 50 \\
\hline
\end{tabular}

The suggested support systems based on the Q-system for the central tunnel and the transversal tunnels are given in Table 5 following the recommendations proposed by Grimstad and Barton [31] using an equivalent diameter of 5.0 and 6.5 for transversal tunnel and central tunnel, respectively.

Table 5. Empirical analysis. Support categories for shale and sandstone formations.

\begin{tabular}{lc}
\hline \multicolumn{1}{c}{ Shale Rock Mass } \\
\hline $\begin{array}{l}\text { Central tunnel } \\
\text { Transversal tunnels }\end{array}$ & $\begin{array}{l}\text { Systematic grouted bolts spaced } 1.4 \mathrm{~m}, L=2.7 \mathrm{~m} \text {, Fibre reinforced shotcrete } 120 \mathrm{~mm} \\
\text { Systematic grouted bolts spaced } 1.4 \mathrm{~m}, L=2.7 \mathrm{~m} \text {, Fibre reinforced shotcrete } 100 \mathrm{~mm}\end{array}$ \\
\hline \multicolumn{1}{c}{ Sandstone Rock Mass } \\
\hline Central tunnel & Systematic grouted bolts spaced $1.7 \mathrm{~m}, L=2.4 \mathrm{~m}$, Fibre reinforced shotcrete $80 \mathrm{~mm}$ \\
Transversal tunnels & Systematic grouted bolts spaced $1.7 \mathrm{~m}, L=2.4 \mathrm{~m}$, Fibre reinforced shotcrete $50 \mathrm{~mm}$ \\
\hline
\end{tabular}

\subsection{Numerical Simulations}

The results of the calculations that have been conducted in sandstone and shale rock masses, in transversal tunnels, the central tunnel and the junction zone between them are shown in this section. Table 3 shows the properties of the support system used in the numerical analysis (bolt diameter, 
length, spacing, load capacity, and thickness of the spayed concrete layer). Figure 4 shows the vertical and horizontal displacements in the transversal tunnels for shale rock mass according to the model indicated in Figure 3a. The maximum displacement is located at the tunnel walls (17.4 mm).

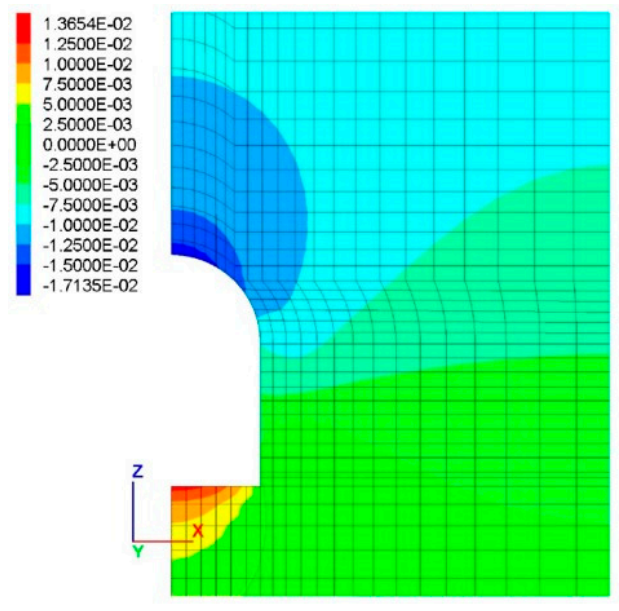

(a)

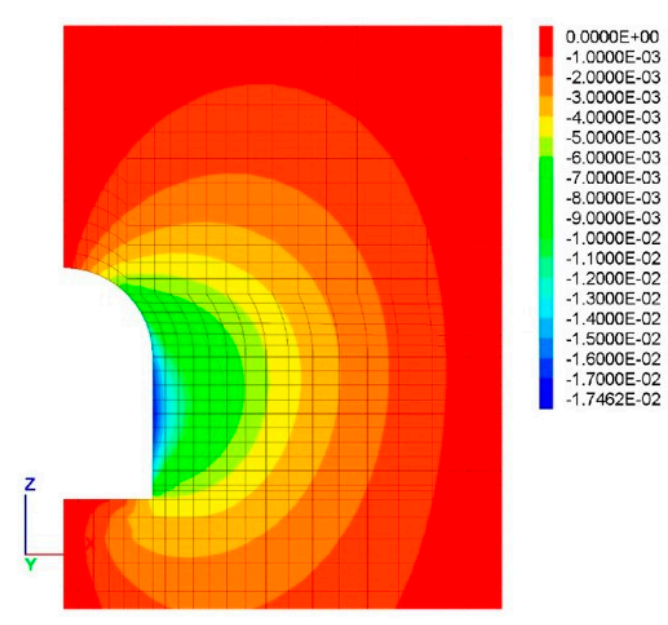

(b)

Figure 4. Transversal tunnels in shale formation: (a) vertical displacements [m]; (b) horizontal displacements [m].

Table 6 shows the summary of the numerical simulations results in transversal tunnels for shale and sandstone rock masses: vertical and horizontal displacements, thickness of the EDZ, axial load in rock bolts and axial force, bending moment and shear force in the shotcrete layer at the walls, roof and floor of tunnels for unsupported and supported cases. By installation of the support, the EDZ and total displacements (vertical and horizontal) notably decreased. Because of the lower quality of the rock mass, in shale formation the displacement values are higher than in sandstone rock mass. The maximum value of displacement reached $17.5 \mathrm{~mm}$ at the walls of the tunnels in shale rock mass. The maximum thickness of EDZ is located at the tunnel walls in shale formation, reaching $2.1 \mathrm{~m}$. In shale formation, the vertical and horizontal displacements are reduced to $12.5 \mathrm{~mm}(27 \%)$ and $14.8 \mathrm{~mm}$ $(15 \%)$, respectively. In sandstone formation, the vertical (roof) and horizontal (walls) displacements are reduced to $1.92 \mathrm{~mm}(34 \%)$ and $2.27 \mathrm{~mm}(22 \%)$, respectively. In addition, the thickness of the EDZ is also reduced by $38 \%$ in shale formation when the support system is applied.

Table 6. Numerical simulations results in transversal tunnels.

\begin{tabular}{lcccc}
\hline \multirow{2}{*}{ Variable } & \multicolumn{2}{c}{ Unsupported Case } & \multicolumn{2}{c}{ Supported Case } \\
\cline { 2 - 5 } & Shale & Sandstone & Shale & Sandstone \\
\hline Vertical displacements $(\mathrm{mm})$ & 17.1 & 2.93 & 12.5 & 1.92 \\
Horizontal displacements $(\mathrm{mm})$ & 17.4 & 2.91 & 14.8 & 2.27 \\
Thickness of EDZ $(\mathrm{m})$ & 2.1 & 0.72 & 1.3 & 0.37 \\
\hline Axial load rock bolts $(\mathrm{kN})$ & & 130.0 & 30.5 \\
\hline \multicolumn{2}{c}{ Axial force $(\mathrm{kN})$} & & 699.46 & 62.41 \\
Shotcrete & Bending moment & & 1.5 & 0.03 \\
& (KNm) & & 5.02 & 0.08 \\
\hline
\end{tabular}

Figure $5 \mathrm{a}$ also shows the rock bolts force for sandstone rock mass. The maximum load in the grouted rock bolts reached $30.5 \mathrm{kN}$ at the tunnel walls. Figure $5 \mathrm{~b}$ shows the failure states for transversal tunnels in sandstone formation as the model reaches equilibrium. A combination of shear and tensile 
failure initiation mechanisms are observed at the floor and walls. The failure mode changes to only shear at the roof of the tunnels. The thickness of the EDZ is $0.72 \mathrm{~m}$ in sandstone formation. The simulation results indicate that the designed support systems can guarantee the tunnels stability.

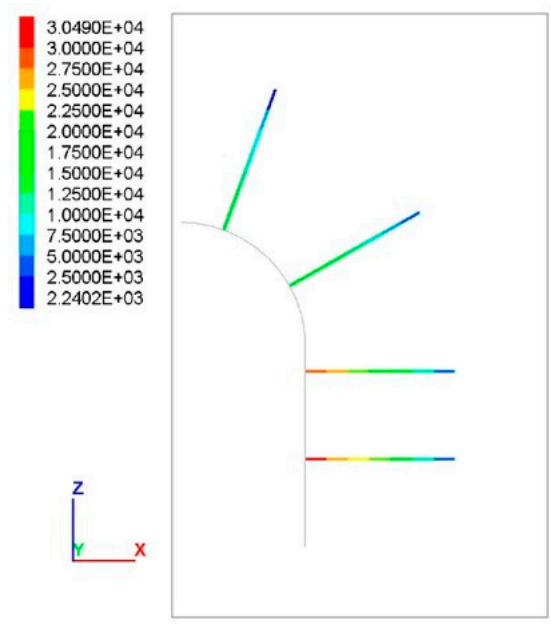

(a)

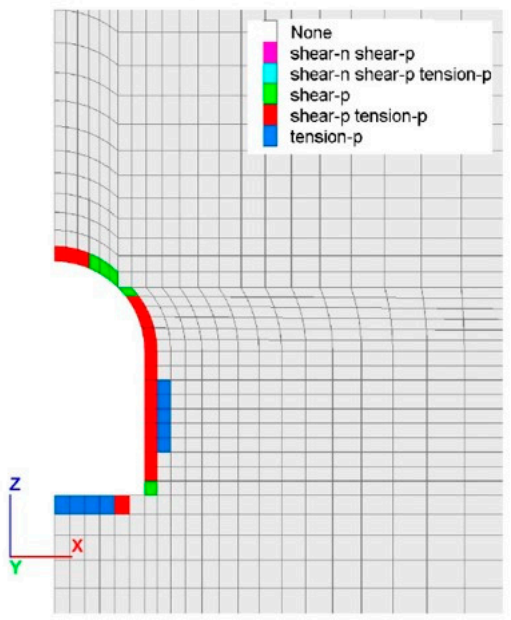

(b)

Figure 5. Transversal tunnels in sandstone formation: (a) rock bolts axial force [N]; (b) state of plasticity.

Figure 6a indicates the rock bolt axial force for transversal tunnels in shale formation. The maximum bolt force is located at the walls of the tunnels $(130 \mathrm{kN})$. Figure $6 \mathrm{~b}$ shows the plasticity zones for shale formation after reaching balance. Shear failure is observed at the roof, walls and floor of the transversal tunnels. The thickness of the EDZ is larger in shale rock mass, reaching a value of $2.1 \mathrm{~m}$. After support installation the thickness of the EDZ is reduced to $1.3 \mathrm{~m}$ in shale formation and $0.37 \mathrm{~m}$ in sandstone formation.

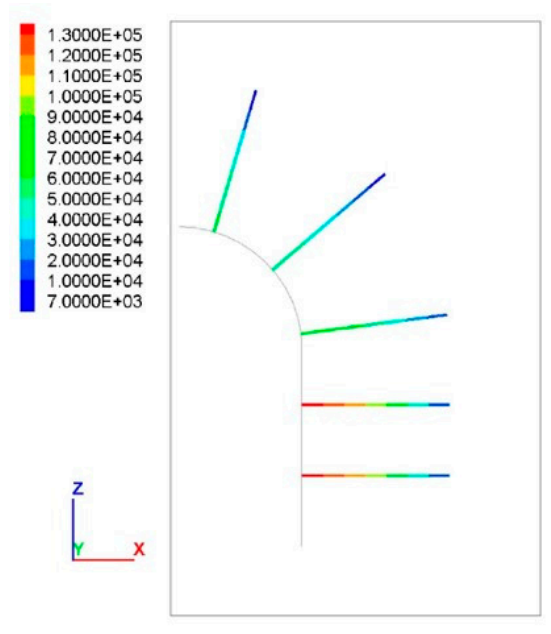

(a)

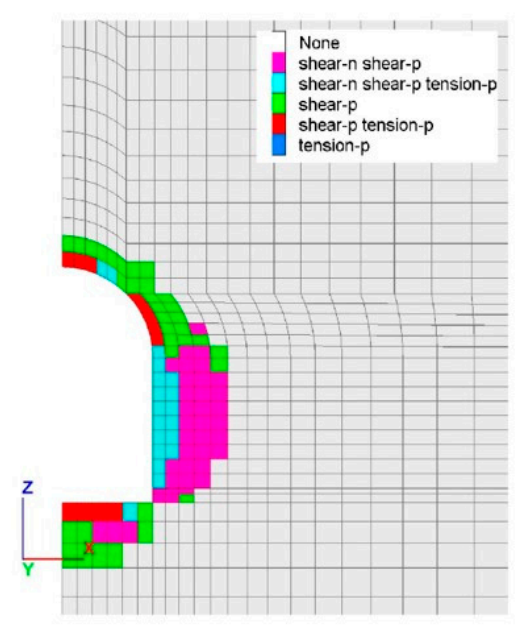

(b)

Figure 6. Transversal tunnels in shale formation: (a) rock bolts axial force $[\mathrm{N}]$; (b) state of plasticity.

In addition to the stability analysis in the transversal tunnels, the state of plasticity and the total displacements have also been analyzed in the central tunnel. Figure 7 shows the axial force in the rock bolts and the state of plasticity in the central tunnel for shale formation. A combination of shear and tensile failure initiation mode is seen at the roof, walls and floor of the central tunnel. Table 7 shows the summary of the numerical simulations results in the central tunnel in shale and sandstone formations for unsupported and supported cases, with the support system indicated previously in Table 3. 


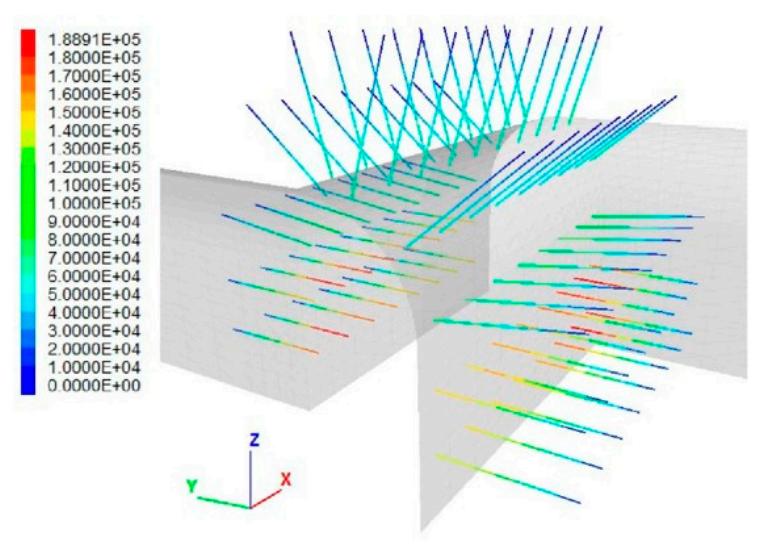

(a)

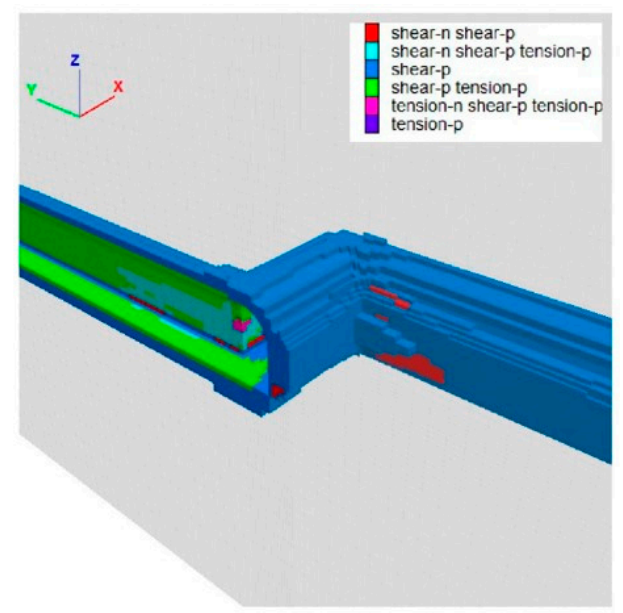

(b)

Figure 7. The central tunnel in shale formation: (a) rock bolts axial force $[\mathrm{N}]$; (b) state of plasticity.

Table 7. Numerical simulation results in the central tunnel.

\begin{tabular}{lcccc}
\hline \multirow{2}{*}{ Variable } & \multicolumn{2}{c}{ Unsupported Case } & \multicolumn{2}{c}{ Supported Case } \\
\cline { 2 - 5 } & Shale & Sandstone & Shale & Sandstone \\
\hline Vertical displacements $(\mathrm{mm})$ & 20.92 & 3.29 & 12.97 & 2.51 \\
Horizontal displacements $(\mathrm{mm})$ & 18.32 & 2.72 & 11.62 & 1.54 \\
Thickness of EDZ $(\mathrm{m})$ & 2.9 & 1.1 & 1.75 & 0.65 \\
\hline Axial load rock bolts $(\mathrm{kN})$ & & & 188.9 & 18.5 \\
\hline \multicolumn{2}{c}{ Axial force $(\mathrm{kN})$} & & 883.64 & 56.29 \\
Shotcrete $\quad$ Bending moment & & 8.08 & 0.16 \\
& SNm) & & 22.35 & 0.42 \\
\hline
\end{tabular}

The maximum value of displacement reached is $20.92 \mathrm{~mm}$ at the roof of the tunnel in shale rock mass. The thickness of the EDZ reached is $2.9 \mathrm{~m}$ is shale formation for the unsupported case. The vertical and horizontal displacements in sandstone formation reach 3.29 and $2.72 \mathrm{~mm}$, respectively. The area of the EDZ and the maximum displacements notably decreased when the support system is applied. In shale formation, the vertical (roof) and horizontal displacements decreased down to $12.97 \mathrm{~mm}(38 \%)$ and $11.62 \mathrm{~mm}(36.5 \%)$, respectively. The rock bolt load reaches a value of $188.9 \mathrm{kN}$ at the walls, while the elastic capacity of the rock bolts is $245 \mathrm{kN}$ (safety factor of 1.29). The axial force, bending moment and shear force in reinforced shotcrete layer have also been analyzed, reaching $883.64 \mathrm{kN}, 8.08 \mathrm{kNm}$, and $22.35 \mathrm{kN}$, respectively, in shale rock mass.

Finally, the stability analysis was carried out in the junction zone between the central and transversal tunnels. Figure $8 \mathrm{a}$ shows the horizontal displacement and Figure $8 \mathrm{~b}$ shows the shear force in the fibre reinforced shotcrete layer. 


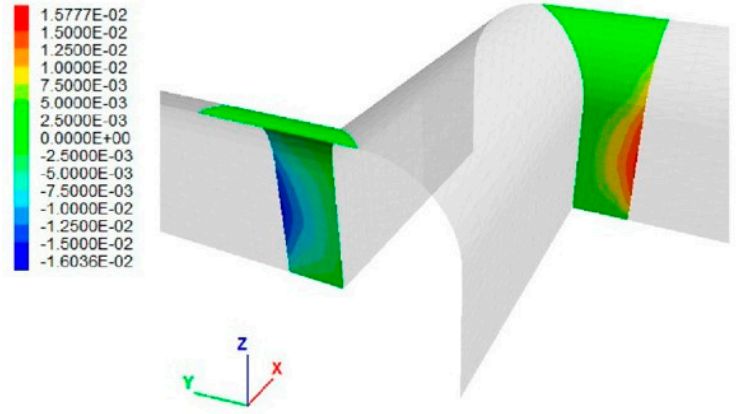

(a)

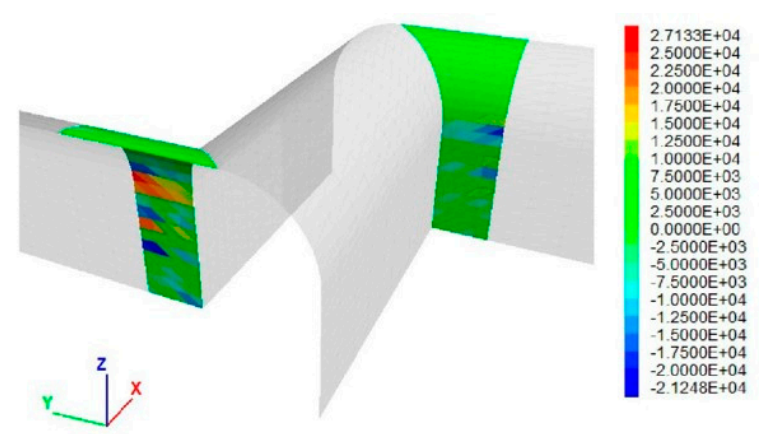

(b)

Figure 8. Junction zone in shale formation: (a) horizontal displacements; (b) shear force in shotcrete.

Table 8 shows the results for the junction zone between the central and transversal tunnels. The maximum value of displacement reached $18.20 \mathrm{~mm}$ at the roof of the tunnels in shale rock mass. By installation of support, the thickness of the EDZ and deformations are reduced. In shale formation, the vertical and horizontal displacements decreased down to $13.84 \mathrm{~mm}$ at the roof and $11.51 \mathrm{~mm}$ in the walls, when the support system is applied. The axial force, bending moment and shear force in reinforced shotcrete layer have also been analyzed in the junction zone, reaching $1570 \mathrm{kN}, 9.31 \mathrm{kNm}$, and $27.13 \mathrm{kN}$, respectively, in shale rock mass. The shear force indicated in Figure $8 \mathrm{~b}$ shows peaks due to the head of the rock bolts.

Table 8. Numerical simulation results in the junction zone.

\begin{tabular}{lcccc}
\hline \multirow{2}{*}{ Variable } & \multicolumn{2}{c}{ Unsupported Case } & \multicolumn{2}{c}{ Supported Case } \\
\cline { 2 - 5 } & Shale & Sandstone & Shale & Sandstone \\
\hline Vertical displacements $(\mathrm{mm})$ & 18.20 & 2.96 & 13.84 & 1.76 \\
Horizontal displacements $(\mathrm{mm})$ & 16.03 & 2.17 & 11.51 & 1.82 \\
Thickness of EDZ $(\mathrm{m})$ & 2.9 & 1.2 & 1.8 & 0.7 \\
\hline Axial load rock bolts $(\mathrm{kN})$ & & & 160.4 & 29.6 \\
\hline \multirow{2}{*}{ Shotcrete $\quad$ Axial force $(\mathrm{kN})$} & Bending moment & & $1,570.0$ & 168.72 \\
& (KNm) & & 9.31 & 0.21 \\
& Shear force $(\mathrm{kN})$ & & 27.13 & 0.59 \\
\hline
\end{tabular}

Figure 9 shows the rock bolts force in the central tunnel and the transversal tunnels depending on the distance from the rock bolt head. Rock bolts located at the walls in shale and sandstone formations have been selected. The maximum axial load is reached in shale rock mass, at the central tunnel. It has been observed that in all scenarios the axial load reached is less than $245 \mathrm{kN}$ (load capacity designed). 


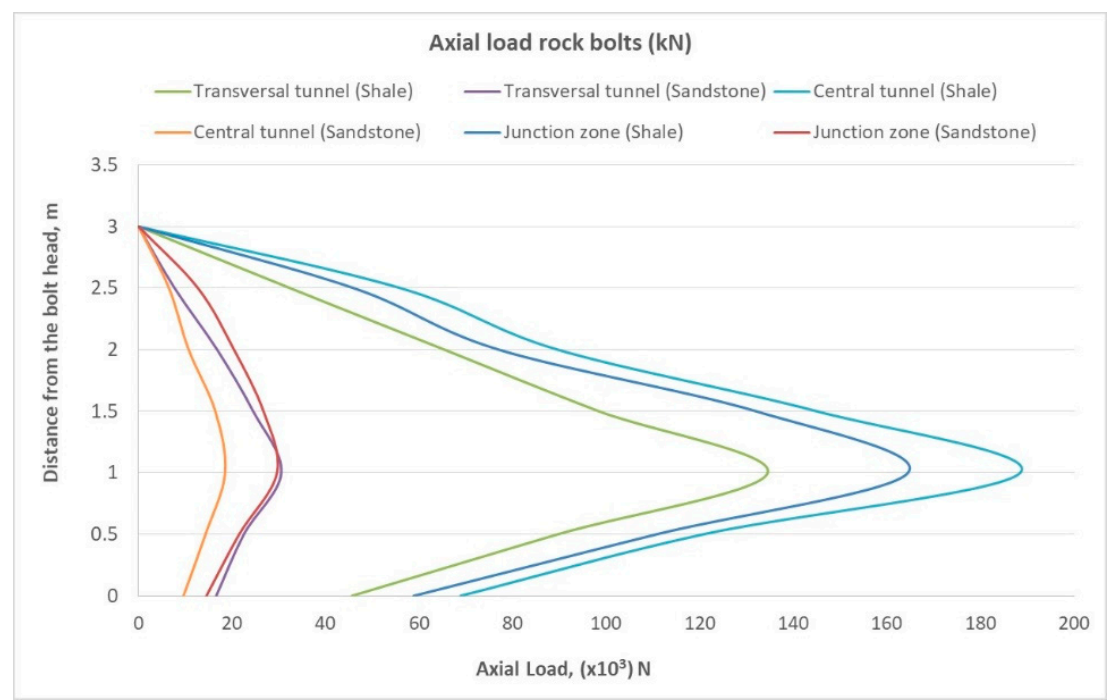

Figure 9. Axial load in rock bolts. Shale and sandstone rock masses.

\section{Conclusions}

Flexible energy storage systems allow increasing the generation of electricity by means of intermittent renewable energy sources. A closed coal mine in the Asturian Central Coal Basin (NW Spain) is proposed as a subsurface water reservoir of underground pumped storage hydropower plants. Underground pumped storage hydropower plants provide a large amount of electrical energy with rapid response and low environmental impacts. An underground reservoir conformed by a network of tunnels with an arched roof cross section of $30 \mathrm{~m}^{2}$ has been designed. For the construction of the underground water reservoir it is necessary to analyze the stability of the excavation of the network of tunnels. Transversal tunnels, the central tunnel and junction zones have been analyzed.

Empirical analysis and three-dimensional numerical simulations have been carried out in this work. According to the empirical analysis, grouted rock bolts and a layer of fibre reinforced shotcrete were recommended as the support system. The rock mass properties used as input parameters for numerical modeling were obtained from laboratory tests and estimated from rock mass classification systems. In the numerical model, the state of plasticity, the axial load in rock bolts and the deformations around the tunnels were analyzed. In addition, the axial force, the bending moment and the shear force were also checked in the reinforced shotcrete layer. The maximum displacements and thickness of the excavation damage zone were reached in shale formation. As shown by the numerical simulations, the proposed support from empirical analysis was feasible. By applying the designed support system, the area of the excavation damage zone and the maximum displacements significantly decreased. The results of the numerical analysis show that no significant failure is expected. All this shows that a combination of empirical and numerical methods is appropriate to design a proper support system in underground infrastructures.

Based on further rock lab testing, a softening factor for the rock mass after failure should be applied in order to get more precise predictions for displacements and the extension of the excavation damage zone as well as the support loads.

Author Contributions: Conceptualization, J.M.; investigation, J.M., F.S., H.K., A.B.S. and J.L.; methodology, J.M. and F.S.; software, J.M., F.S.; validation, J.M, F.S., H.K. and A.B.S.; writing original draft, J.M. and F.S.; writing review and editing, J.M., A.B.S. and J.L.; supervision, F.S., H.K., A.B.S. and J.L. All authors have read and agreed to the published version of the manuscript.

Funding: This research received no external funding.

Conflicts of Interest: The authors declare no conflict of interest. 


\section{Nomenclature}

$\begin{array}{ll}\text { 3D } & \text { Three-dimensional } \\ \text { ACCB } & \text { Asturian Central Coal Basin } \\ \text { CAES } & \text { Compressed air energy storage } \\ \text { EDZ } & \text { Excavation damage zone } \\ \text { ESR } & \text { Excavation support ratio } \\ \text { FESS } & \text { Flexible energy storage system } \\ \text { GSI } & \text { Geological strength index } \\ \text { MC } & \text { Mohr-Coulomb } \\ \text { PSH } & \text { Pumped-storage hydropower } \\ \text { RQD } & \text { Rock quality designation, } \\ \text { SFR } & \text { Steel fibre reinforced shotcrete } \\ \text { SRF } & \text { Stress reduction factor } \\ \text { UPSH } & \text { Underground pumped-storage hydropower } \\ \text { VRE } & \text { Variable renewable energies }\end{array}$

\section{References}

1. Menéndez, J.; Fernández-Oro, J.M.; Loredo, J. Economic feasibility of underground pumped storage hydropower plants providing ancillary services. Appl. Sci. 2020, 10, 3947. [CrossRef]

2. U.S. Energy Information Administration (EIA). International Energy Statistics. Available online: https: //www.iea.org/ (accessed on 20 August 2020).

3. International Renewable Energy Agency. Renewables and Electricity Storage: A Technology Roadmap for Remap 2030; IREA: Abu Dhabi, UAE, 2015.

4. Wong, I.H. An underground pumped storage scheme in the bukit Timah granite of Singapore. Tunn. Undergr. Space Technol. 1996, 11, 485-489. [CrossRef]

5. Kucukali, S. Finding the most suitable existing hydropower reservoirs for the development of pumped-storage schemes: An integrated approach. Renew. Sustain. Energy Rev. 2014, 37, 502-508. [CrossRef]

6. Minakshi, M.; Mitchell, D.R.G.; Jones, R.T.; Pramanik, N.C.; Jean-Fulcrand, A.; Garnweitner, G. A hybrid electrochemical energy storage device using sustainable electrode materials. Chem. Sel. 2020, 5, 1597-1606. [CrossRef]

7. Divakaran, A.M.; Hamilton, D.; Manjunatha, K.N.; Minakshi, M. Design, development and thermal analysis of reusable Li-Ion battery module for future mobile and stationary applications. Energies 2020, 13, 1477. [CrossRef]

8. Menéndez, J.; Schmidt, F.; Konietzky, H.; Fernández-Oro, J.M.; Galdo, M.; Loredo, J.; Díaz-Aguado, M.B. Stability analysis of the underground infrastructure for pumped storage hydropower plants in closed coal mines. Tunn. Undergr. Space Technol. 2019, 94. [CrossRef]

9. Uddin, N.; Asce, M. Preliminary design of an underground reservoir for pumped storage. Geotech. Geol. Eng. 2003, 21, 331-355. [CrossRef]

10. Carneiro, J.F.; Matos, C.R.; van Gessel, S. Opportunities for large-scale energy storage in geological formations in mainland Portugal. Renew. Sustain. Energy Rev. 2019, 99, 201-211. [CrossRef]

11. Khaledi, K.; Mahmoudi, E.; Datcheva, M.; Schanz, T. Analysis of compressed air storage caverns in rock salt considering thermomechanical cyclic loading. Environ. Earth Sci. 2016, 75. [CrossRef]

12. Liu, J.; Zhao, X.D.; Zhang, S.J.; Xie, L.K. Analysis of support requirements for underground water-sealed oil storage cavern in China. Tunn. Undergr. Space Technol. 2018, 71, 36-46. [CrossRef]

13. Chen, J.; Lu, D.; Liu, W.; Fan, J.; Jiang, D.; Yi, L.; Kang, Y. Stability study and optimization design of small-spacing two-well (SSTW) salt caverns for natural gas storages. J. Energy Storage 2020, 27. [CrossRef]

14. Rutqvist, J.; Kim, H.M.; Ryu, D.W.; Synn, J.H.; Song, W.K. Modeling of coupled thermodynamic and geomechanical performance of underground compressed air energy storage in lined rock caverns. Int. J. Rock Mech. Min. Sci. 2012, 52, 71-81. [CrossRef]

15. Zhu, W.S.; Li, X.J.; Zhang, Q.B.; Zheng, W.H.; Xin, X.L.; Sun, A.H.; Li, S.C. A study on sidewall displacement prediction and stability evaluations for large underground power station caverns. Int. J. Rock Mech. Min. Sci. 2010, 47, 1055-1062. [CrossRef] 
16. Harza, R.D. Hydro and pumped storage for peaking. Power Eng. 1960, 64, 79-82.

17. Isaaksson, G.; Nilsson, D.; Sjostrand, T. Pumped storage power plants with underground lower reservoirs. In Proceedings of the Seventh World Power Conference, Moscow, Russia, 20-24 August 1968; Section 2. p. 160.

18. Sorensen, K.E. Underground reservoirs: Pumped storage of the future? Civ. Eng. 1969, 39, 66-70.

19. Dames and Moore. An Assessment of Hydroelectric Pumped Storage. National Hydroelectric Power Resources Study. Under Contract No. DACW-31-80 C-0090 to US Army Corps of Engineers. 1981. Available online: https://www.iwr.usace.army.mil/Portals/70/docs/iwrreports/IWR019-000001-000517.pdf (accessed on 20 August 2020).

20. Tam, S.W.; Blomquist, C.A.; Kartsounes, G.T. Underground pumped hydro storage-An overview. Energy Sources 1979, 4, 329-351. [CrossRef]

21. Braat, K.B.; Van Lohuizen, H.P.S.; De Haan, J.F. Underground pumped hydro-storage project for the Netherlands. Tunn. Tunn. 1985, 17, 19-22.

22. Menendez, J.; Loredo, J.; Fernandez-Oro, J.M.; Galdo, M. Energy storage in underground coal mines in NW Spain: Assessment of an underground lower water reservoir and preliminary energy balance. Renew. Energy 2019, 134, 1381-1391. [CrossRef]

23. Menéndez, J.; Loredo, J.; Fernández-Oro, J.M.; Galdo, M. Underground Pumped-Storage Hydro Power Plants with Mine Water in Abandoned Coal Mines. In Proceedings of the 2017 International Mine water Association Congress 'Mine Water and Circular Economy', Lappeenranta, Finland, 25-30 June 2017; Wolkersdorfer, C., Sartz, L., Sillanpää, M., Häkkinen, A., Eds.; LUT Scientific and Expertise Publications: Lappeenranta, Finland, 2017; pp. 6-13.

24. Wessel, M.; Madlener, R.; Hilgers, C. Economic Feasibility of Semi-Underground Pumped Storage Hydropower Plants in Open-Pit Mines. Energies 2020, 13, 4178. [CrossRef]

25. Luick, H.; Niemann, A.; Perau, E.; Schreiber, U. Coalmines as Underground Pumped Storage Power Plants (UPP)—A contribution to a sustainable energy supply? Geophys. Res. Abstr. 2012, 14, 4205.

26. Madlener, R.; Specht, J.M. An Exploratory Economic Analysis of Underground Pumped-Storage Hydro Power Plants in Abandoned Coal Mines; FCN Working Paper No. 2/2013; FCN: Aachen, Germany, 2013.

27. Pujades, E.; Orban, P.; Archambeau, P.; Kitsikoudis, V.; Erpicum, S.; Dassargues, A. Underground pumped-storage hydropower (UPSH) at the martelange mine (Belgium): Interactions with groundwater flow. Energies 2020, 13, 2353. [CrossRef]

28. Kitsikoudis, V.; Archambeau, P.; Dewals, B.; Pujades, E.; Orban, P.; Dassargues, A.; Pirotton, M.; Erpicum, S. Underground Pumped-Storage Hydropower (UPSH) at the Martelange Mine (Belgium): Underground Reservoir Hydraulics. Energies 2020, 13, 3512. [CrossRef]

29. Menéndez, J.; Fernandez-Oro, J.M.; Galdo, M.; Loredo, J. Efficiency analysis of underground pumped storage hydropower plants. J. Energy Storage 2020, 28. [CrossRef]

30. Barton, N.; Lien, R.; Lunde, J. Engineering classification of rock masses for the design of tunnel support. Rock Mech. 1974, 6, 189-236. [CrossRef]

31. Grimstad, E.; Barton, N. Updating the Q-system for NMT. In Proceedings of the Int. Symp. Sprayed Concrete, Fagernes, Norway, 17-21 October 1993; Norwegian Concrete Association: Oslo, Norway, 1993; pp. $46-66$.

32. Barton, N. Some new Q-value correlations to assist in site characterization and tunnel design. Int. J. Rock Mech. Min. Sci. 2002, 39, 185-216. [CrossRef]

33. Goel, R.K.; Jethwa, J.L.; Paithankar, A.G. Indian experiences with Q and RMR systems. Tunn. Undergr. Space Technol. 1995, 10, 97-109. [CrossRef]

34. Ulusay, R. The ISRM Suggested Methods for Rock Characterization, Testing and Monitoring: 2007-2014; Springer International Publishing: Cham, Switzerland, 2015.

35. Ray, A.K. Influence of cutting sequence on development of cutters and roof falls in underground coal mine. In Proceedings of the 28th International Conference on Ground Control in Mining, Morgantown, WV, USA, 28-30 July 2009; Peng, S.S., Ed.; West Virginia University: Morgantown, WV, USA, 2009.

(C) 2020 by the authors. Licensee MDPI, Basel, Switzerland. This article is an open access article distributed under the terms and conditions of the Creative Commons Attribution (CC BY) license (http://creativecommons.org/licenses/by/4.0/). 